\title{
Suppression of Meloidogyne incognita by the Entomopathogenic Fungus Lecanicillium muscarium
}

\author{
Manzoor Hussain, ${ }^{\dagger}$ Miloslav Zouhar, and Pavel Ryšánek, Czech University of Life Sciences, Faculty of Agrobiology, Food and Natural \\ Resources, Department of Plant Protection, Kamycka 129, 16521 Prague, Czech Republic
}

\begin{abstract}
The entomopathogenic fungus Lecanicillium muscarium (Petch) Zare and Gams is currently being developed as a biocontrol agent against insect pests, as well as some plant-pathogenic fungi and bacteria. Data about its activity against plant-parasitic nematodes exist, but are relatively limited. To expand this understanding, we investigated the biocontrol efficiency of three isolates of L. muscarium (Lm) against the root knot nematode, Meloidogyne incognita, in both in vitro and in vivo conditions. In our experiments, the maximum number of nematode eggs, juveniles (J2s), females, and egg masses that were parasitized were quantified after a 72-h exposure to the fungus. The isolate $\mathrm{Lm} 1$ was designated as the best biocontrol agent against

nematode eggs as well as J2s. It showed the highest colonization of eggs and significantly decreased egg hatching events. The results from two additional isolates, $\mathrm{Lm} 2$ and $\mathrm{Lm} 3$, were also significant $(P=0.05)$ but less pronounced than those observed with $\mathrm{Lm} 1$. L. muscarium treatments had significant $(P=0.05)$ positive effects on plant shoot and root growth compared with the growth of control plants. These results suggest the effectiveness of the fungus may be due to either the infection of eggs and $\mathrm{J} 2 \mathrm{~s}$, or the production of secondary metabolites that induced plant defense mechanisms and lead to systemic resistance. Our study demonstrates that $L$. muscarium could be used as a potential biocontrol agent against root knot nematodes.
\end{abstract}

Root knot nematodes (Meloidogyne spp.) are some of the most destructive polyphagous pests with a wide host range that includes field crops, vegetables, and ornamental plants (Anwar and McKenry 2010; Mai and Abawi 1987). These nematodes contribute to more than $10 \%$ of crop production losses worldwide (Anastasiadis et al. 2008; Anwar and McKenry 2012; Topp et al. 1998; Whitehead 1998). When selecting pesticides for use in today's agriculture, several critical factors are considered. These factors include low toxicity to human and wildlife populations, limited environmental impact, and restricting chemical residues in the food supply. Extensive use of these harmful chemicals by the farming community in order to achieve desirable crop yields is creating an imbalance in our ecosystem. Moreover, due to the deleterious effects of nematicides on human health and the environment, it is important to introduce new, alternative control measures. Scientists are working diligently to identify promising alternatives to combat the nematode threat without the use of biohazardous chemicals. To date, many biocontrol agents have been studied and some are commercially available. A variety of nematode antagonists have been reported, including protozoans, viruses, bacteria, and fungi. In particular, fungal antagonists have been extensively studied with the aim of using them to limit populations of soilborne nematodes (Chen and Dickson 2004). Nematophagous fungi have been considered as a potential tool to capture and colonize nematode eggs and motile second stage juveniles (J2) in plant root zones via the production of direct or indirect trapping structures. Recently, the genus Verticillium has been reclassified based on rDNA sequencing and all entomopathogenic species in this genus were placed in the separate genus Lecanicillium (Gams and Zare 2001; Zare and Gams 2001; Zare et al. 2000), including L. attenuatum, L. lecanii, L. longisporum, L. nodulosum, and L. muscarium.

L. muscarium is an entomopathogenic mitosporic fungus with the capability to act as a multipurpose microbial control agent against a wide range of insect pests, plant pathogenic fungi, and plant parasitic nematodes. It has been isolated from various hosts, although mostly from insects, fungi, and nematodes, and has been commercialized as a biopesticide under the trade names of Mycotal and Verticillin,

${ }^{\dagger}$ Corresponding author: M. Hussain; E-mail: hussain@af.czu.cz

Funding: We are thankful to Czech University of Life Sciences Prague for providing funds to conduct part of this research under CIGA No. 20152016.

Accepted for publication 5 December 2017.

(c) 2018 The American Phytopathological Society which target white flies, thrips, and aphids and mites, respectively (de Faria and Wraight 2007). It has been reported that Lecanicillium spp. successfully parasitizes the eggs of $M$. incognita (Gan et al. 2007; Nguyen et al. 2007), and the females, cysts, and eggs of Heterodera glycines under both lab and greenhouse conditions (Hussain et al. 2017a, b; Meyer et al. 1997). Additionally, it has been observed that eggs containing immature J2s are more susceptible to Lecanicillium spp. (Chen and Chen 2003; Irving and Kerry 1986; Kim and Riggs 1991). To infect their host, $L$. muscarium conidia adhere to the host cuticle, germinate, penetrate, and produce blastospores inside the nematode eggs and $\mathrm{J} 2 \mathrm{~s}$. The fungus also produces various toxic metabolites that act to disarm hosts or induce resistance in plants in order to overcome other pathogens (Hirano et al. 2008).

The objective of this study was to investigate the pathogenicity of L. muscarium on M. incognita under both lab and greenhouse conditions. Three isolates of $L$. muscarium originally collected from egg masses of M. incognita in Samsun Province (Black Sea Region of Turkey) were used. The isolates had been maintained in tubes containing Sabouraud dextrose agar and deposited in the fungal culture collection of the Department of Plant Protection, Faculty of Agriculture, Ondokuz Mayis University, Samsun.

\section{Materials and Methods}

Nematode culture. The $M$. incognita population used here originated from Samsun Province (Black Sea Region) in Turkey. It was collected from cucumber roots, identified morphologically, and then cultured and maintained on a susceptible tomato variety, Beril. Infected roots were brought into the lab, washed with running tap water, and egg masses and females were collected with forceps. Roots were surface sterilized in $0.5 \%$ sodium hypochlorite for $2 \mathrm{~min}$, followed by three washes with sterile water, and then placed in 10-ml tubes supplemented with the antibiotic streptomycin at a concentration of $1 \mathrm{~g} /$ liter before incubation at $25^{\circ} \mathrm{C}$. After 10 days, the contents of each tube were poured onto tissue in Baermann funnels, and after $24 \mathrm{~h}$ the $\mathrm{J} 2 \mathrm{~s}$ that hatched were collected, counted, and used for testing. To determine the parasitic activity of $L$. muscarium on eggs and females, the handpicked egg masses and females were placed in a $0.05 \%$ sodium hypochlorite solution for $2 \mathrm{~min}$, with frequent stirring, followed by three washes with distilled water. The eggs released from dissolution of the gelatinous matrix were further surface sterilized in $0.05 \%$ sodium hypochlorite followed by three washes with sterile water.

Fungal cultures. Three isolates of the fungus were L. muscarium isolated from the egg masses of $M$. incognita collected from the same location as those nematodes used for experimentation. The three 
L. muscarium isolates were tested against the same nematode population on the susceptible tomato cultivar Beril. They were typed according to molecular techniques (Zare and Gams 2008), purified on potato dextrose agar (PDA) supplemented by streptomycin at a concentration of $1 \mathrm{~g} /$ liter, and incubated at $25^{\circ} \mathrm{C}$ for 10 days. Conidia were harvested in deionized water containing $0.03 \%$ Tween 80 and filtered through four layers of sterile cheesecloth to remove mycelium (Güçlü et al. 2010). Conidia were counted and standardized using a hemocytometer under compound microscope. The conidial suspension was adjusted to $1 \times 10^{3}$ conidia/ml for each fungal isolate and sprayed on agar media for lab experiments (Güçlü et al. 2010). Viability of the conidia was confirmed before each experiment using methods previously described by Wekesa et al. (2005) with some modifications. In all cases, the viability was close to $100 \%$.

Lab studies. Determining the effect of fungi on eggs. Of each fungal isolate, $1 \mathrm{ml}$ of a conidial suspension $\left(1 \times 10^{3} \mathrm{conidia} / \mathrm{ml}\right)$ was inoculated onto the center of a $60 \times 15 \mathrm{~mm}$ Petri dish containing PDA medium. Plates were incubated at $25^{\circ} \mathrm{C}$ for 1 week and then uniformly coated using a glass rod with $100 \mathrm{M}$. incognita eggs. Five replicates for each fungal isolate were performed, and eggs inoculated onto plates without fungus were maintained as a negative control for comparison. Fungal activity on the eggs was evaluated after 24,48 , and $72 \mathrm{~h}$. Production of conidia for each isolate was also measured after $72 \mathrm{~h}$. The number of parasitized eggs was counted under light microscopy after staining with cotton blue. Eggs parasitized by fungal hyphae or with observed disintegration of their contents were considered infected (Khan et al. 2006; Singh and Mathur 2010). Eggs containing live J2s were counted as viable. The experiment was repeated three times with five replications each.

Measuring the effect of fungi on egg hatching. Sterile Petri dishes containing PDB were plated with 100 eggs and fungal spores of each isolate with concentration of $1 \times 10^{3}$ conidia/ml supplemented with $1 \mathrm{~g} /$ liter streptomycin in order to avoid bacterial contamination. Plates were then incubated at room temperature for 10 days. After this period, J2 numbers were counted under a stereomicroscope and percentage of hatched eggs were determined. Sterile water and noninoculated PDB cultures were included as controls. The experiment was repeated three times with five replications each.

Evaluating the effect of fungi on nematode activity and mortality. One milliliter $\left(1 \times 10^{3}\right.$ conidia) of each fungal isolate and $1 \mathrm{ml}$ of nematode $\mathrm{J} 2$ suspension containing $100 \mathrm{~J} 2 \mathrm{~s} / \mathrm{ml}$ were placed on sterile Petri dishes. The suspensions were spread uniformly with a sterile glass rod. Potato dextrose broth (PDB) medium was used for this study. Ten replicates for each isolate were used. Nematode activity was determined after 24, 48, and $72 \mathrm{~h}$. Fungus efficacy was measured based on the numbers of paralyzed nematodes present. Rigid, elongated, and curved $\mathrm{J} 2 \mathrm{~s}$ were considered immobilized if they did not react after probing with a fine needle (Cayrol et al. 1989; Singh and Mathur 2010). The PDB media was washed off, nematodes were collected, and revival tests were run by centrifugation for $3 \mathrm{~min}$ at $1,000 \mathrm{rpm}$ and incubation in sterile water for 1 day. If nematodes were found inactive after 1 day, they were considered dead. The experiment was repeated three times with five replications each.

Determining the effect of fungi on females and egg masses. Tests were conducted to determine the efficacy of fungus isolates on nematode females and egg masses. For this, 100 nematode females and egg masses were taken and each one was separately placed on a Petri plate and exposed to each fungal isolate with suspension of $1 \times 10^{3}$ conidia/ml. PDB media was used and conidial suspension was put at the sides of the plates. The numbers of infected females and egg masses were counted under microscopy after 24,48 , and $72 \mathrm{~h}$. The experiment was repeated three times with five replications each.

Greenhouse experiments. In vivo experiments were carried out using the susceptible tomato variety Beril. Seeds were surface sterilized in $0.05 \% \mathrm{NaOCl}$ for $5 \mathrm{~min}$ and then seeded in peat soil. Three-week-old seedlings were transplanted to pots $\left(20 \mathrm{~cm}\right.$ diameter; $\left.2,000 \mathrm{~cm}^{3}\right)$ containing $2 \mathrm{~kg}$ of sterilized soil, at one seedling per pot. The soil (sand 62\%; silt $17 \%$; clay $20 \%$; $\mathrm{pH} 7.2$; organic matter $1 \%$ ) had been sterilized at $160^{\circ} \mathrm{C}$ for $3 \mathrm{~h}$ for these experiments. After planting, $5 \mathrm{ml}$ of fungal isolate suspension containing $10^{4}$ conidia was poured into each pot and the treated seedlings were placed on the greenhouse bench in a completely randomized fashion. Two weeks after inoculation with fungus, 3,000 nematode eggs or freshly hatched J2s (24-h-old) were introduced into each pot. Both inoculations of nematodes and fungi were performed near root zones of the plants by making small holes. The control plants included those without nematode and fungus, with only nematode eggs and J2s, or only fungus. Each fungal isolate was used for treatment on five replicate plants and the entire experiment was repeated once. The greenhouse temperature ranged between 25 and $30^{\circ} \mathrm{C}$. Plants were added to each pot with urea once a week, harvested after 8 weeks, and the data were recorded.

Data collection. After 8 weeks, tomato plants were carefully uprooted from the pots and their roots were removed from the shoots. The roots were gently washed and blotted dry. Root and shoot length and fresh and dry weights were recorded. Numbers of galls were counted. Root systems were stained by Phloxin B and egg masses were counted under the stereomicroscope at $40 \times$ magnification. For the estimation of total nematode population size, eggs were extracted from individual root systems (Hussey and Barker 1973) and juveniles were extracted from the soil of each individual plant in their respective pots (Whitehead and Hemming 1965). The total numbers of eggs and nematodes in the soil were counted and comprised the total nematode population. The reproduction factor was calculated by dividing the final population by 3,000. Roots were cross sectioned, dyed, and examined under a microscope to quantify mycelia of fungi.

Data analysis. The lab experiment was done three times with five replications whereas greenhouse studies were repeated once. Data from greenhouse experiments were pooled and subjected to ANOVA tests; means were partitioned by least significant difference (LSD) test with the software Statistica 8.1.

\section{Results}

In vitro experiments. Infection of $M$. incognita by the three fungus isolates differed according to the isolate, with isolate Lm1 generally resulting in higher infection levels, and Lm3 in lower infection levels. Infection levels of all isolates increased over time, and after $72 \mathrm{~h}$ at least $88 \%$ of eggs, egg masses, J2s, and females were infected by isolate Lm1. Furthermore, only $5 \%$ of eggs in the Lm1 treatment hatched, compared with $96 \%$ in the control. The difference between isolates in the efficacy of nematode infection was reflected in the conidia production, as Lm1 had the highest, and Lm3 the lowest conidia production (Table 1, Fig. 1).

Table 1. In vitro effects of three Lecanicillium muscarium isolates on root knot nematodes, Meloidogyne incognita eggs, egg masses, females, juveniles (J2s), and hatching over time ${ }^{\mathrm{z}}$

\begin{tabular}{|c|c|c|c|c|c|c|c|c|c|c|c|c|c|c|}
\hline \multirow{2}{*}{$\begin{array}{l}\text { L. muscarium } \\
\text { isolates/Treatments }\end{array}$} & \multicolumn{3}{|c|}{$\begin{array}{c}\text { Percent egg } \\
\text { infection at different time } \\
\text { intervals of exposure }\end{array}$} & \multirow{2}{*}{$\begin{array}{c}\begin{array}{c}\text { Percent } \\
\text { egg } \\
\text { hatching }\end{array} \\
10 \text { days }\end{array}$} & \multicolumn{3}{|c|}{$\begin{array}{l}\text { Percent female infection at } \\
\text { different time intervals }\end{array}$} & \multicolumn{3}{|c|}{$\begin{array}{l}\text { Percent } \mathrm{J} 2 \text { infection at } \\
\text { different time intervals }\end{array}$} & \multicolumn{3}{|c|}{$\begin{array}{l}\text { Percent infection of egg } \\
\text { masses at different time } \\
\text { intervals }\end{array}$} & \multirow{2}{*}{$\begin{array}{c}\begin{array}{c}\text { Production } \\
\text { of fungal } \\
\text { conidia/100 } \mathbf{~ m m}^{2}\end{array} \\
72 \mathrm{~h}\end{array}$} \\
\hline & $24 \mathrm{~h}$ & $48 \mathrm{~h}$ & $72 \mathrm{~h}$ & & $24 \mathrm{~h}$ & $48 \mathrm{~h}$ & $72 \mathrm{~h}$ & $24 \mathrm{~h}$ & $48 \mathrm{~h}$ & $72 \mathrm{~h}$ & $24 \mathrm{~h}$ & $48 \mathrm{~h}$ & $72 \mathrm{~h}$ & \\
\hline $\mathrm{Lm} 1$ & $23 \pm 3 a$ & $42 \pm 4 a$ & $89 \pm 5 a$ & $5 \pm 1 \mathrm{~d}$ & $16 \pm 1 \mathrm{a}$ & $42 \pm 2 \mathrm{a}$ & $94 \pm 2 \mathrm{a}$ & $8 \pm 3 a$ & $67 \pm 7 \mathrm{a}$ & $89 \pm 4 a$ & $39 \pm 2 a$ & $63 \pm 3 a$ & $88 \pm 5 a$ & $1.66 \times 10^{3} \pm 3 \mathrm{a}$ \\
\hline $\mathrm{Lm} 2$ & $10 \pm 1 b$ & $25 \pm 5 b$ & $67 \pm 7 b$ & $10 \pm 3 c$ & $11 \pm 2 b$ & $23 \pm 4 b$ & $72 \pm 3 b$ & $17 \pm 3 b$ & $32 \pm 3 b$ & $71 \pm 2 b$ & $14 \pm 4 b$ & $32 \pm 3 b$ & $66 \pm 2 b$ & $1.41 \times 10^{3} \pm 2 b$ \\
\hline $\mathrm{Lm} 3$ & $8 \pm 1 b$ & $18 \pm 3 b$ & $55 \pm 4 b$ & $23 \pm 1 b$ & $8 \pm 1 c$ & $11 \pm 2 \mathrm{c}$ & $49 \pm 4 c$ & $9 \pm 2 c$ & $31 \pm 4 b$ & $48 \pm 6 c$ & $13 \pm 2 c$ & $14 \pm 4 \mathrm{c}$ & $49 \pm 4 c$ & $1 \times 10^{3} \pm 3 c$ \\
\hline $\begin{array}{l}\text { PDB medium } \\
\text { (control) }\end{array}$ & $00 \pm 0 \mathrm{c}$ & $1 \pm 1 \mathrm{c}$ & $2 \pm 1 \mathrm{c}$ & $96 \pm 3 \mathrm{a}$ & $00 \pm 0 \mathrm{~d}$ & $1 \pm 1 \mathrm{~d}$ & $03 \pm 1 \mathrm{~d}$ & $00 \pm 0 \mathrm{~d}$ & $2 \pm 1 \mathrm{c}$ & $5 \pm 1 \mathrm{~d}$ & $00 \pm 0 \mathrm{~d}$ & $2 \pm 1 \mathrm{~d}$ & $3 \pm 1 \mathrm{~d}$ & $00 \pm 0 \mathrm{~d}$ \\
\hline $\begin{array}{l}\text { Distilled water } \\
\text { (control) }\end{array}$ & $00 \pm 0 \mathrm{c}$ & $3 \pm 1 \mathrm{c}$ & $6 \pm 2 c$ & $97 \pm 2 \mathrm{a}$ & $00 \pm 0 \mathrm{~d}$ & $00 \pm 0 \mathrm{~d}$ & $02 \pm 1 \mathrm{~d}$ & $00 \pm 0 \mathrm{~d}$ & $2 \pm 1 \mathrm{c}$ & $7 \pm 2 \mathrm{~d}$ & $00 \pm 0 \mathrm{~d}$ & $00 \pm 0 \mathrm{~d}$ & $2 \pm 1 \mathrm{~d}$ & $00 \pm 0 \mathrm{~d}$ \\
\hline
\end{tabular}

\footnotetext{
${ }^{\mathrm{z}}$ Data are means of 15 replications. Means within a column followed by the same letter are not significantly different according to T-test at $P=0.05$.
} 
There was limited disintegration found in nematode eggs, females, J2 population, and egg masses in control treatments, which was significantly less than fungal treatments. The conidial production per unit area of Petri dish was much higher in Lm1 than in Lm2 and Lm3, which was a clear picture of fungal activity against nematodes (Table 1).

Greenhouse experiments. Nematode reproduction parameters. The impact of the three fungal isolates on nematode reproduction and plant growth was investigated. Significant reductions $(P=0.05)$ were observed in the number of galls, egg masses, eggs per root system, J2 production levels, and nematode reproduction factor $(\mathrm{Pf} / \mathrm{Pi})$, compared with that of the control plants. All three isolates were found effective in reducing plant infection levels either inoculated with eggs or freshly hatched $\mathrm{J} 2 \mathrm{~s}$ (Table 2). Individual comparison of means indicated that Lm1 was significantly $(P=0.05)$ able to reduce the formation of galls and egg masses from both egg and $\mathrm{J} 2$ application (Table 2). The results observed from isolates $\mathrm{Lm} 2$ and $\mathrm{Lm} 3$ were also significant $(P=0.05)$ but less pronounced than those of Lm1. All three isolates reduced Pf/Pi both in egg and $\mathrm{J} 2$ treated plants, compared with controls. Comparison of means demonstrated that results from the three isolates (Lm1, Lm2, and $\mathrm{Lm} 3$ ), regarding egg and $\mathrm{J} 2$ production and $\mathrm{Pf} / \mathrm{Pi}$, were not significantly different from each other, but were highly significant $(P=0.05)$ compared with controls (Table 2). Results clearly show that when plants were treated with an initial inoculum of J2s or eggs, Lm1 successfully decreased the number of galls and egg masses by more than 80 and $90 \%$, respectively (Table 2 ). In the case of $\mathrm{Lm} 3$, final populations were reduced by up to $99.46 \%$ when plants had been inoculated with J2s. However, Lm1 was ranked first in reduction of final nematode populations $(99.73 \%)$ when plants were inoculated with eggs. The data strongly suggest that Lm1 was more aggressive toward eggs than J2s.

Plant growth parameters. $M$. incognita did not negatively affect all plant growth parameters. In the control plants without fungus, shoot weights and lengths were negatively affected by $M$. incognita, except for dry shoot weights following J2 inoculation. Root weights were increased but shoot lengths were decreased (Tables 3 and 4). All three isolates of L. muscarium resulted in increased plant growth parameters, with the exception of root weight, compared with control (without fungus) plants. Calculating the reduction percentage confirmed that fresh and dry weight of the roots was reduced by up to 77 and $81 \%$, respectively, when plants were treated with J2s. Likewise, Lm1 showed a remarkable impact on reducing the same parameters (up to 78 and 89\%) when plants were treated with eggs. Lm1 application without nematodes resulted in the highest weights of fresh and dry shoots except fresh shoot length $(P=0.05)$ compared with both control plants and those treated with the other fungal isolates. Isolate $\mathrm{Lm} 2$ also had a significant effect $(P=0.05)$ on all parameters measured compared with controls; these effects were less pronounced than those of Lm1, but more pronounced than Lm3. Among the isolates, Lm3 proved to be less efficient than $\mathrm{Lm} 2$ in its ability to protect against both eggs and J2s. Lm3 did not significantly $(P=0.05)$ affect fresh shoot lengths compared with the control (Table 3). Moreover, all fungal isolates were observed to be more efficient when parasitizing eggs compared with the $\mathrm{J} 2$ stage of nematodes (Table 3). Taken together, the data show that Lm1 had the highest pathogenicity against nematode eggs, as well as J2s, among the isolates tested. Furthermore, it appeared that the roots were more fibrous and healthy when plants had been treated with $\mathrm{J} 2 \mathrm{~s}$ and fungus compared with those treated with eggs and fungus. Ample growth of foliage and roots in the plants treated with fungus alone was observed, indicating positive effects of fungal treatment (Table 3), and extensive colonization was seen when cross sections of roots were observed under light microscopy.

\section{Discussion}

The protective activity of three $L$. muscarium isolates against $M$. incognita was evaluated in both in vitro and in vivo conditions. All three isolates exhibited varying degrees of nematicidal effects on $M$. incognita eggs as well as J2s. Through in vitro experiments, Lm1 was proven to be the most aggressive isolate, resulting in higher mortality of eggs, $\mathrm{J} 2 \mathrm{~s}$, females, and egg masses, closely followed by Lm 2 and Lm3. It was also noted that antagonistic fungal activity increased with treatment time (Meyer et al. 2004). Following $72 \mathrm{~h}$ of fungus exposure, only a few eggs hatched into J2s, and a mat of hyphae could be observed inside the eggs.
Eggs were examined both structurally and morphologically and were found to be swollen, anamorphic, and deformed. The egg shells had lost their original structural features and were partially degraded during observation with the light microscope. Moreover, there were large vacuoles in the egg chitin layer, thought to be caused by the high level of chitinases, proteases, and collagenases in fungi (Gan et al. 2007).

The growth and production of conidia of $\mathrm{Lm} 1$ on PDA medium was faster than that for either Lm2 or Lm3. Thus, Lm1 had an advantage in parasitizing more eggs and $\mathrm{J} 2 \mathrm{~s}$ than was possible by Lm2 and Lm3. Lm1 produced more substantial effects on egg hatching and the penetration of mycelium in females compared with other parameters. The PDB and water (control) treatment did not show any nematicidal effects on either soybean cyst nematode eggs or J2s, which also supports the results of Nitao et al. (1999), who found lower egg hatching rates in PDB than in water. Conversely, Meyer et al. (2000) reported that immersion of $M$. incognita eggs in PDB could stimulate hatch compared with water controls. It appeared that there was no direct effect of fungal culture $\mathrm{pH}$ on egg hatching and $\mathrm{J} 2$ killing, which agrees with the

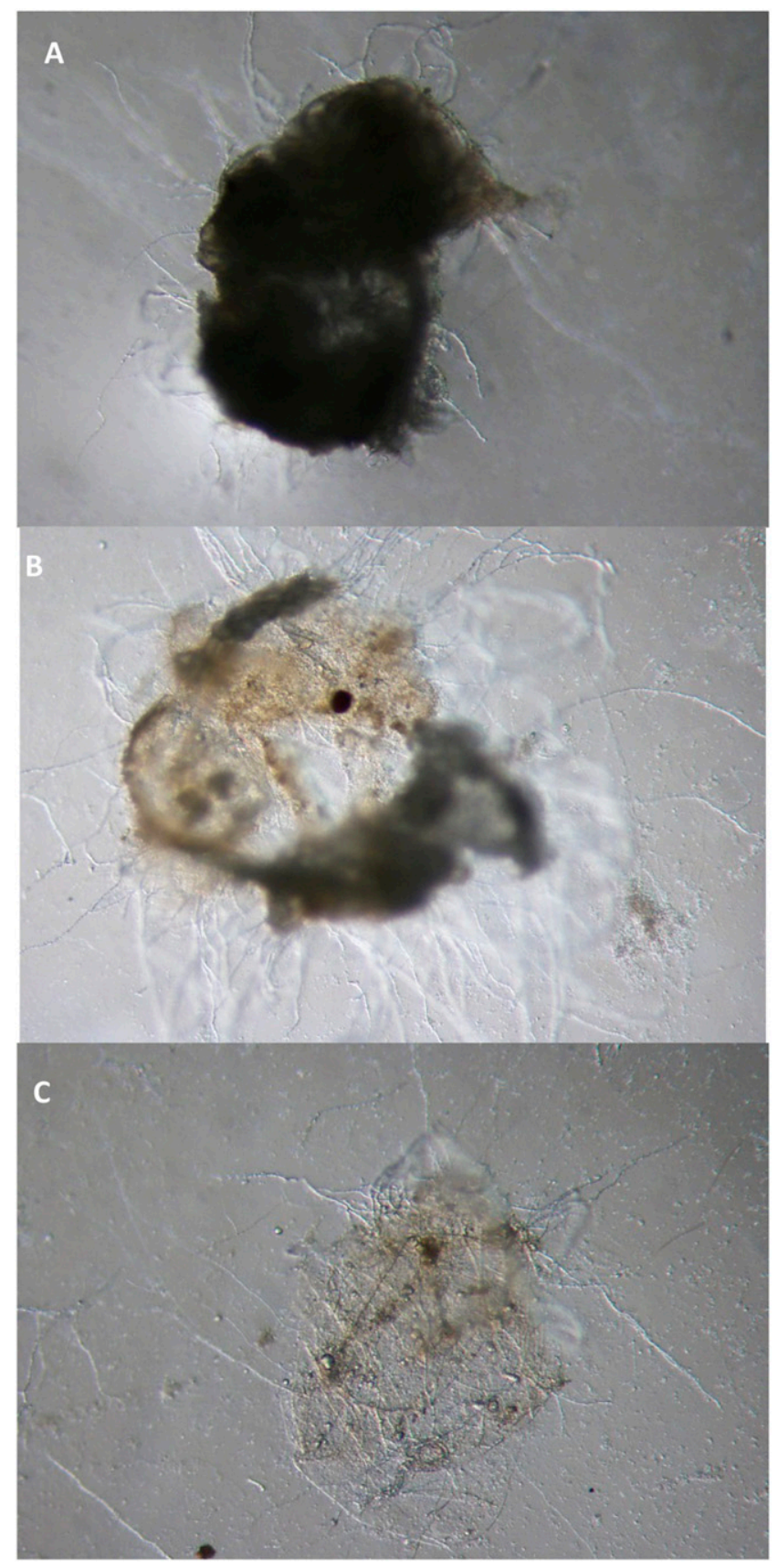

Fig. 1. Disintegration of Meloidogyne incognita female by Lecanicillium muscarium (Lm1) after three exposure intervals of $24 \mathrm{~h} \mathrm{(A),} 48 \mathrm{~h}(\mathbf{B})$, and $72 \mathrm{~h}(\mathbf{C})$. 
conclusions of Shinya et al. (2008). We assumed that the levels of enzymes or other active compounds produced by fungus Lm1 was much higher than that of $\mathrm{Lm} 2$ and $\mathrm{Lm} 3$ during fungal culturing on PDA (Shinya et al. 2008). Immature eggs were more susceptible to penetration and killing by fungus (Bonants et al. 1995; Gan et al. 2007). Fungal penetration of eggs might be enabled by the high production of extracellular cuticle-degrading protease (Yang et al. 2005, 2007) because the cuticle of nematode eggs is composed of a complex structure of proteinous and chitinous compounds (Cox et al. 1981). Therefore, an invading fungus must produce several types of enzymes to overcome this barrier (Khan et al. 2003; Tikhonov et al. 2002).
This fungus had been previously known to produce some antagonistic compounds that could greatly influence their parasitism of eggs and inhibition of J2s (Benedict and Brady 1972; Hirano et al. 2008; Singh and Mathur 2010). Overall, all three isolates were found to be efficient against $M$. incognita nematodes, but Lm1 possessed the most antagonistic capabilities for reducing egg hatching levels and inducing mortality in juveniles and females. The differences in nematode parasitism between these isolates was probably due to much more robust and faster growth and production of metabolic compounds by mycelium isolate Lm1.

The effects of these isolates on nematodes and plant growth were additionally confirmed in greenhouse experiments. It was observed

Table 2. Effect of Lecanicillium muscarium on root knot nematodes, Meloidogyne incognita on tomato plants under greenhouse studies using nematode eggs or $\mathrm{J} 2 \mathrm{~s}$ as initial inoculum ${ }^{\mathrm{x}}$

\begin{tabular}{|c|c|c|c|c|c|c|c|c|c|c|}
\hline \multirow[b]{2}{*}{$\begin{array}{l}\text { L. muscarium } \\
\text { isolates }\end{array}$} & \multirow{2}{*}{$\begin{array}{l}\text { M. incognita } \\
\text { (using 3,000 } \\
\text { eggs or J2 ) }\end{array}$} & \multicolumn{2}{|c|}{ Per root system } & \multicolumn{2}{|c|}{ Indices } & \multicolumn{2}{|c|}{ Egg production } & \multicolumn{2}{|c|}{ Juveniles production } & \multirow[b]{2}{*}{$\mathbf{P f} / \mathbf{P i} \mathbf{y}$} \\
\hline & & Galls & $\begin{array}{c}\text { Egg } \\
\text { masses }\end{array}$ & Gall & $\begin{array}{c}\text { Egg } \\
\text { mass }\end{array}$ & $\begin{array}{c}\text { Per root } \\
\text { system }\end{array}$ & Per root (g) & Per root system & $\begin{array}{l}\text { Per } 100 \mathrm{cc} \\
\text { of soil }\end{array}$ & \\
\hline$\overline{\mathrm{Lm} 1}$ & $F$ & $20 \pm$ & $14 \pm$ & 3 & 3 & 4 & $476 \pm 11.2 \mathrm{c}$ & $12.3 \mathrm{~d}$ & $509 \pm 5$ & $5.3=$ \\
\hline $\mathrm{Lm}$ & & $26 \pm$ & & 3 & 3 & & & & & \\
\hline Lm3 & Eggs & $34 \pm 7.8 b$ & & 4 & 3 & & $\mathrm{~b}$ & & $8 \mathrm{c}$ & $1.05 \mathrm{~b}$ \\
\hline Lm1 & $\mathrm{J} 2$ & $19 \pm 2.4 \mathrm{~d}$ & $15 \pm$ & 3 & 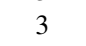 & $4,094 \pm$ & $530=$ & $9 \mathrm{c}$ & $9 \mathrm{~d}$ & $5.9 \pm 1.09 \mathrm{~d}$ \\
\hline $\mathrm{Lm} 2$ & $\mathrm{~J} 2$ & $23 \pm 4.3 c$ & $18 \pm 1.2 \mathrm{c}$ & 3 & 3 & $5,410 \pm 14 c$ & $564 \pm 8.9 \mathrm{c}$ & $1,744 \pm 13.4 \mathrm{bc}$ & $836 \pm 8.5 b$ & $7.9 \pm 1.9 \mathrm{c}$ \\
\hline Lm3 & $\mathrm{J} 2$ & $34 \pm 7.5 b$ & $24 \pm 2.7 b$ & 4 & 3 & $7,104 \pm 13.2 b$ & $664 \pm 9.2 b$ & $1,923 \pm 12.9 \mathrm{~b}$ & $906 \pm 7.8 \mathrm{~b}$ & $9.0 \pm 1.7 \mathrm{~b}$ \\
\hline No fungus ${ }^{z}$ & Eggs & $126 \pm 5.7 \mathrm{a}$ & $101 \pm 5.9 \mathrm{a}$ & 5 & 5 & $31,874 \pm 10.7 \mathrm{a}$ & $2,191 \pm 11.3 \mathrm{a}$ & $14,858 \pm 13.2 \mathrm{a}$ & $1,310 \pm 7.8 \mathrm{a}$ & $24.3 \pm 1.7 \mathrm{a}$ \\
\hline No fungus ${ }^{z}$ & $\mathrm{~J} 2$ & $124 \pm 5.9 \mathrm{a}$ & $94 \pm 4.8 \mathrm{a}$ & 5 & 4 & $32,574 \pm 12.7 \mathrm{a}$ & $2,310 \pm 13.4 \mathrm{a}$ & $14,800 \pm 13.1 \mathrm{a}$ & $1,332 \pm 8.2 \mathrm{a}$ & $24.7 \pm 2 \mathrm{a}$ \\
\hline
\end{tabular}

${ }^{x}$ Data are means of 10 replications; means within a column followed by the same letter are not significantly different according to LSD test at $P=0.05$. Gall and egg mass indices are a $0-5$ scale, where $0=$ no galls or egg masses, $1=1-2$ galls or egg masses; $2=3-10$ galls or egg masses; $3=11-30$ galls or egg masses; $4=$ 31-100 galls or egg masses, and 5=>100 galls or egg masses per root system (Quesenberry et al. 1989).

y $\mathrm{Pf} / \mathrm{Pi}$ is the reproduction factor $(\mathrm{RF})$, where the final nematode population density (Pf) is divided by the initial nematode population density (Pi).

${ }^{\mathrm{z}}$ Control, without application of fungi.

Table 3. Effect of Lecanicillium muscarium on root knot nematodes, Meloidogyne incognita, and plant growth of tomato under greenhouse studies using nematode eggs as initial inoculum ${ }^{\mathrm{w}}$

\begin{tabular}{|c|c|c|c|c|c|c|c|}
\hline L. muscarium & $\begin{array}{l}\text { M. incognita } \\
\text { (using } \\
\text { 3,000 eggs) }\end{array}$ & Fresh root wt (g) & Dry root wt (g) & Fresh shoot wt (g) & Dry shoot wt (g) & $\begin{array}{c}\text { Fresh root length } \\
(\mathrm{cm})\end{array}$ & $\begin{array}{c}\text { Fresh shoot length } \\
(\mathrm{cm})\end{array}$ \\
\hline Lm1 & Eggs & $9 \pm 0.9 \mathrm{~d}$ & $1.9 \pm 0.02 \mathrm{f}$ & $10.4 \pm 0.97 \mathrm{c}$ & $3.4 \pm 0.99 b$ & $33.4 \pm 3.2 \mathrm{bc}$ & $38.7 \pm 2.9 \mathrm{a}$ \\
\hline $\mathrm{Lm} 2$ & Eggs & $10.5 \pm 0.9 \mathrm{c}$ & $3.3 \pm 0.4 \mathrm{~d}$ & $10.1 \pm 1.14 \mathrm{~cd}$ & $2.9 \pm 0.79 \mathrm{~cd}$ & $32.9 \pm 4.2 \mathrm{c}$ & $34.7 \pm 3.4 \mathrm{~d}$ \\
\hline $\mathrm{Lm} 3$ & Eggs & $10.1 \pm 1.7 \mathrm{c}$ & $4.2 \pm 0.19 b c$ & $9.7 \pm 0.94 \mathrm{~d}$ & $2.3 \pm 0.63 \mathrm{e}$ & $31.9 \pm 2.1 \mathrm{~d}$ & $33.5 \pm 3.1 \mathrm{e}$ \\
\hline $\operatorname{Lm} 1^{x}$ & No nematodes & $11.4 \pm 2.1 \mathrm{~b}$ & $4.6 \pm 0.5 b$ & $12.08 \pm 1.02 \mathrm{a}$ & $3.8 \pm 1.03 \mathrm{a}$ & $34.3 \pm 2.3 \mathrm{a}$ & $36.4 \pm 2.8 \mathrm{~b}$ \\
\hline $\operatorname{Lm} 2^{x}$ & No nematodes & $10.8 \pm 1.9 \mathrm{bc}$ & $4 \pm 0.09 c$ & $11.3 \pm 2.1 \mathrm{~b}$ & $3.2 \pm 0.91 b c$ & $33.8 \pm 3.7 \mathrm{ab}$ & $35.2 \pm 3.2 \mathrm{c}$ \\
\hline $\operatorname{Lm} 3^{x}$ & No nematodes & $10.4 \pm 1.2 \mathrm{c}$ & $2.7 \pm 0.2 \mathrm{e}$ & $10.5 \pm 1.5 \mathrm{c}$ & $2.8 \pm 0.72 \mathrm{~d}$ & $33.3 \pm 4.3 \mathrm{bc}$ & $35.5 \pm 4.2 \mathrm{c}$ \\
\hline No fungus ${ }^{y}$ & Eggs & $14.6 \pm 1 \mathrm{a}$ & $5.8 \pm 0.9 \mathrm{a}$ & $4.2 \pm 1.89 \mathrm{f}$ & $0.95 \pm 0.02 \mathrm{~g}$ & $27.6 \pm 2.8 \mathrm{e}$ & $16.9 \pm 3.03 \mathrm{f}$ \\
\hline No fungus ${ }^{z}$ & No nematodes & $7.7 \pm 1.3 \mathrm{e}$ & $3.5 \pm 0.7 \mathrm{~d}$ & $6.06 \pm 1.09 \mathrm{e}$ & $1.2 \pm 0.21 \mathrm{f}$ & $32.2 \pm 2.3 \mathrm{~d}$ & $35.3 \pm 3.4 \mathrm{c}$ \\
\hline
\end{tabular}

${ }^{\text {w }}$ Data are means of 10 replications; means within a column followed by the same letter are not significantly different according to LSD test at $P=0.05$.

${ }^{x}$ Control, only fungi without nematodes.

y Control, without application of fungi.

${ }^{\mathrm{z}}$ Control, without fungi and nematodes.

Table 4. Effect of Lecanicillium muscarium on root knot nematodes, Meloidogyne incognita, and plant growth of tomato under greenhouse studies using nematode $\mathrm{J} 2 \mathrm{~s}$ as initial inoculum ${ }^{\mathrm{w}}$

\begin{tabular}{|c|c|c|c|c|c|c|c|}
\hline L. muscarium & $\begin{array}{c}\text { M. incognita } \\
\text { (using 3,000 } \\
\text { J2s) }\end{array}$ & Fresh root wt (g) & Fresh shoot wt (g) & Dry root wt (g) & Dry shoot wt (g) & $\begin{array}{c}\text { Fresh root length } \\
\text { (cm) }\end{array}$ & $\begin{array}{c}\text { Fresh shoot length } \\
(\mathrm{cm})\end{array}$ \\
\hline Lm1 & $\mathrm{J} 2 \mathrm{~s}$ & $8.4 \pm 1.2 \mathrm{e}$ & $10.2 \pm 1.2 \mathrm{c}$ & $2 \pm 0.2 \mathrm{f}$ & $3.2 \pm 0.9 \mathrm{~b}$ & $32.7 \pm 3.2 \mathrm{bcd}$ & $38.8 \pm 1.9 \mathrm{a}$ \\
\hline $\mathrm{Lm} 2$ & $\mathrm{~J} 2 \mathrm{~s}$ & $10.2 \pm 1.2 \mathrm{~d}$ & $9.9 \pm 1.4 \mathrm{~cd}$ & $3.2 \pm 0.4 \mathrm{~d}$ & $2.9 \pm 0.9 \mathrm{bc}$ & $32.4 \pm 2.9 \mathrm{cde}$ & $34.2 \pm 1.8 \mathrm{de}$ \\
\hline Lm3 & $\mathrm{J} 2 \mathrm{~s}$ & $11.5 \pm 1.2 \mathrm{~b}$ & $9.5 \pm 1.9 \mathrm{~d}$ & $4.2 \pm 0.5 \mathrm{bc}$ & $2.2 \pm 0.7 \mathrm{~d}$ & $31.6 \pm 2.9 \mathrm{e}$ & $33.5 \pm 3.1 \mathrm{e}$ \\
\hline $\operatorname{Lm} 1^{x}$ & No nematodes & $11.2 \pm 1.3 \mathrm{bc}$ & $12.1 \pm 0.8 \mathrm{a}$ & $4.5 \pm 0.9 \mathrm{~b}$ & $3.7 \pm 1 \mathrm{a}$ & $34.3 \pm 3.1 \mathrm{a}$ & $36 \pm 1.9 \mathrm{~b}$ \\
\hline $\operatorname{Lm} 2^{x}$ & No nematodes & $10.5 \pm 1.2 \mathrm{~cd}$ & $10.8 \pm 1.2 \mathrm{~b}$ & $3.9 \pm 0.9 \mathrm{c}$ & $3.2 \pm 0.8 b$ & $33.5 \pm 2.8 \mathrm{ab}$ & $34.9 \pm 1.7 \mathrm{~cd}$ \\
\hline $\operatorname{Lm} 3^{x}$ & No nematodes & $10.3 \pm 1.3 \mathrm{~d}$ & $10.2 \pm 1.5 \mathrm{c}$ & $2.7 \pm 0.6 \mathrm{e}$ & $2.8 \pm 0.8 \mathrm{c}$ & $33.2 \pm 2.9 \mathrm{bc}$ & $35.2 \pm 2.4 b c$ \\
\hline No fungus ${ }^{y}$ & No nematodes & $7.9 \pm 0.9 \mathrm{e}$ & $5.9 \pm 0.8 \mathrm{e}$ & $3.5 \pm 1 \mathrm{~d}$ & $1.3 \pm 0.4 \mathrm{e}$ & $32 \pm 2.1 \mathrm{de}$ & $35 \pm 2.3 \mathrm{~cd}$ \\
\hline No fungus ${ }^{z}$ & $\mathrm{~J} 2 \mathrm{~s}$ & $14.5 \pm 1.8 \mathrm{a}$ & $3.9 \pm 0.9 \mathrm{f}$ & $5.9 \pm 1.3 \mathrm{a}$ & $0.9 \pm 0.03 \mathrm{e}$ & $27.7 \pm 2.3 \mathrm{f}$ & $16.5 \pm 1.9 \mathrm{f}$ \\
\hline
\end{tabular}

${ }^{\mathrm{w}}$ Data are means of 10 replications; means within a column followed by the same letter are not significantly different according to LSD test at $P=0.05$.

${ }^{x}$ Control, only fungi without nematodes.

y Control, without fungi and nematodes.

${ }^{\mathrm{z}}$ Control, without application of fungi. 
that $\mathrm{Lm} 1$ most significantly $(P=0.05)$ affected nematode reproduction factors and plant growth parameters, followed by $\mathrm{Lm} 2$ and Lm3. Isolate $\mathrm{Lm} 1$ proved to be more effective in reducing the number of galls, egg masses, eggs, and $\mathbf{J} 2$ production compared with nontreated plants. $\mathrm{Lm} 2$ and $\mathrm{Lm} 3$ demonstrated an intermediate effect on reducing numbers of galls, egg masses, $\mathrm{J} 2$ population, and $\mathrm{Pf} / \mathrm{Pi}$. Although all three isolates had great potential in reducing $\mathrm{Pf} / \mathrm{Pi}$ of the final $\mathrm{J} 2$ and egg population, Lm1 was the most aggressive of the group, which could be due to fast growth properties or the stimulation of host resistance against nematodes (Hirano et al. 2008). Efficacy of $L$. muscarium may also be correlated to temperature $\left(5\right.$ to $\left.30^{\circ} \mathrm{C}\right)$ with an optimum at $25^{\circ} \mathrm{C}$ (Fenice et al. 1996, 1997; Hussain et al. 2017c, d). Moreover, during examination of the root systems, more extensive colonization and penetration was found in the Lm1-treated plants than in those treated by Lm2 or Lm3. Nematode-related plant disease receded with greater colonization of fungus (Hirano et al. 2008; Koike et al. 2001); however, in the case of $\mathrm{Lm} 2$ and $\mathrm{Lm} 3$, the plant roots were not colonized to a great extent. Therefore, we may suppose that a longer association of fungus with host roots could further deter nematodes from penetration (Koike et al. 2004; Meera et al. 1994). Moreover, that root system obtained from application of both $\mathrm{J} 2 \mathrm{~s}$ and fungus was observed to be more fibrous and healthy compared with the roots that had been inoculated with both fungus and eggs. This could be due to $\mathrm{J} 2$ initial infection that resulted in the initiation and proliferation of more secondary roots (Williamson and Hussey 1996; Wyss et al. 1992). We also included controls to ensure that fungus alone did not have any negative effects on these plants, and observed improved growth with fungal treatment alone compared with plants that were left untreated by either fungus or nematodes. Our results strongly suggest that these fungi probably produce growth promoting hormones that are capable of stimulating plant growth regardless of pathogen presence.

\section{Literature Cited}

Anastasiadis, I. A., Giannakou, I. O., Prophetou, A. D. A., and Gowen, S. R. 2008. The combined effect of the application of a biocontrol agent Paecilomyces lilacinus, with various practices for the control of root-knot nematodes. Crop Prot. 27:352-361.

Anwar, S. A., and McKenry, M. V. 2010. Incidence and reproduction of Meloidogyne incognita on vegetable crop genotypes. Pak. J. Zool. 42:135-141.

Anwar, S. A., and McKenry, M. V. 2012. Incidence and population density of plant-parasitic nematodes infecting vegetable crops and associated yield losses. Pak. J. Zool. 44:327-333.

Benedict, R. G., and Brady, L. R. 1972. Antimicrobial activities of mushroom metabolites. J. Pharm. Sci. 61:1820-1822.

Bonants, P. J. M., Fitters, P. F. L., Thijs, H., den Belder, E., Waalwijk, C., and Henfling, J. W. D. M. 1995. A basic serine protease from Paecilomyces lilacinus with biological activity against Meloidogyne hapla eggs. Microbiol. 141:775-784.

Cayrol, J. C., Djian, C., and Pijarowski, L. 1989. Study of the nematocidal properties of the culture filtrate of the nematophagus fungus Paecilomy ceslilacinus. Rev. Nematologie. 12:331-336.

Chen, S., and Dickson, W. 2004. Biological control of nematode by fungal antagonists. Pages 979-1039 in: Nematology: Advances and Perspectives. Vol. 2: Nematode Management and Utilization. Z. X. Chen, S. Y. Chen, and D. W. Dickson, eds. CAB International, Wallingford, U.K.

Chen, S. Y., and Chen, F. J. 2003. Fungal parasitism of Heterodera glycines eggs as influenced by egg age and pre-colonization of cysts by other fungi. J. Nematol. 35:271-277.

Cox, G. N., Kusch, M., and Edgar, R. S. 1981. Cuticle of Caenorhabditis elegans: its isolation and partial characterization. J. Cell Biol. 90:7-17.

de Faria, M. R., and Wraight, S. P. 2007. Mycoinsecticides and Mycoacaricides: A comprehensive list with worldwide coverage and international classification of formulation types. Biol. Control 43:237-256.

Fenice, M., Seibmann, L., Giambattista, R., Petruccioli, M., and Federici, F. 1996. Production of extracellular chitinolytic activities by a strain of the antarctic entomogenous fungus Verticillium cfr. Lecanii. Pages 285-292 in: Chitin Enzymology. R. A. A. Muzzarelli, ed. Vol. 2. Atec Edizioni, Grottammare, Italy.

Fenice, M., Seibmann, L., Zucconi, L., and Onofri, S. 1997. Production of extracellular enzymes by antarctic fungal strain. Polar Biol. 17:275-280.

Gams, W., and Zare, R. 2001. A revision of Verticillium Sect. Prostrata. III. Genetic classification. Nova Hedwigia 72:329-337.

Gan, Z. W., Yang, J. K., Tao, N., Liang, L. M., Mi, Q., Li, J., and Zhang, K. Q. 2007. Cloning of the gene Lecanicillium psalliotae chintinase LpChil and identification of its potential role in the biocontrol of root knot nematode Meloidogyne incognita. Appl. Microbiol. Biotechnol. 76:1309-1317.
Güçlü, S., Ak, K., Eken, C., Akyol, H., Sekban, R., Beytut, B., and Yildirim, R. 2010. Pathogenicity of Lecanicillium muscarium against Ricania simulans. Bull. Insectology 63:243-246.

Hirano, E., Koike, M., Aiuchi, D., and Tani, M. 2008. Pre-inoculation of cucumber roots with Verticillium lecanii (Lecanicillium muscarium) induces resistance to powdery mildew. Res. Bull. Obihiro Univ. 29:82-94.

Hussain, M., Zouhar, M., and Rysanek, P. 2017a. Comparison between biological and chemical management of sugar beet nematode, Heterodera schachtii. Pak. J. Zool. 49:45-50

Hussain, M., Zouhar, M., and Rysanek, P. 2017b. Effect of some nematophagous fungi on reproduction of a nematode pest, Heterodera schachtii, and growth of sugar beet. Pak. J. Zool. 49:189-196.

Hussain, M., Zouhar, M., and Rysanek, P. 2017c. Population dynamics of a nematophagous fungus, Lecanicillium muscarium, and root knot nematode, Meloidogyne incognita to assess the disease pressure and its management. Pak. J. Zool. 49:197-204.

Hussain, M., Zouhar, M., and Rysanek, P. 2017d. Potential of some nematophagous fungi against Meloidogyne hapla infection in Czech Republic. Pak. J. Zool. 49:35-43.

Hussey, R. S., and Barker, K. R. 1973. A comparison of methods of collecting inocula of Meloidogyne spp. including a new technique. Plant Dis. Rep. 57:1025-1028.

Irving, F., and Kerry, B. R. 1986. Variation between strains of the nematophagous fungus, Verticillium chlamydosporium Goddard. II. Factors affecting parasitism of cyst nematode eggs. Nematologica 32:474-485.

Khan, A., Williams, K., Molloy, M. P., and Nevalainenc, H. 2003. Purification and characterization of a serine protease and chitinases from Paecilomyces lilacinus and detection of chitinase activity on 2D gels. Protein Expr. Purif. 32:210-220.

Khan, A., Williams, K. L., and Nevalainen, H. K. M. 2006. Control of plantparasitic nematodes by Paecilomyces lilacinus and Monacrosporium lysipagum in pot trials. Biol. Control 51:643-658.

Kim, D. G., and Riggs, R. D. 1991. Characteristics and efficacy of a sterile hyphomycete (ARF18), a new biocontrol agent for Heterodera glycines and other nematodes. J. Nematol. 23:275-282.

Koike, M., Higashio, T., Komori, A., Akiyama, K., Kishimoto, N., Masuda, E., Sasaki, M., Yoshida, S., Tani, M., Kuramoti, K., Sugimoto, M., and Nagao, H. 2004. Verticillium lecanii (Lecanicillium spp.) as epiphyte and its application to biological control of arthropod pests and diseases. IOBC WPRS Bull. 27:41-44

Koike, N., Hyakumachi, M., Kageyama, K., Tsuyumu, S., and Doke, N. 2001 Induction of systemic resistance in cucumber against several diseases by plant growth promoting fungi: lignification and superoxide generation. Eur. J. Plant Pathol. 107:523-533.

Mai, W. F., and Abawi, G. S. 1987. Interactions among root-knot nematodes and fusarium wilt fungi on host plants. Annu. Rev. Phytopathol. 25:317-338.

Meera, M. S., Shivanna, M. B., Kageyama, K., and Hyakumachi, M. 1994. Plant growth promoting fungi from zoysia grass rhizosphere as potential inducers of systemic resistance in cucumbers. Phytopathol. 84:1399-1406.

Meyer, S. L. F., Huettel, R. N., Liu, X. Z., Humber, R. A., Juba, J., and Nitao, J. K. 2004. Activity of fungal culture filtrates against soybean cyst nematode and root-knot nematode egg hatch and juvenile motility. Nematol. 6:23-32.

Meyer, S. L. F., Johnson, G., Dimock, M., Fahey, J. W., and Huettel, R. N. 1997 Field efficacy of Verticillium lecanii, sex pheromone, and pheromone analogs as potential management agents for soybean cyst nematode. J. Nematol. 29: 282-288.

Meyer, S. L. F., Massoud, S. I., Chitwood, D. J., and Roberts, D. P. 2000 Evaluation of Trichoderma virens and Burkholderia cepacia for antagonistic activity against root-knot nematode, Meloidogyne incognita. Nematol. 2:871-879.

Nguyen, N. V., Kim, Y. J., Oh, K. T., Jung, W. J., and Park, R. D. 2007. The role of chitinase from Lecanicillium antillanum B-3 in parasitism to root-knot nematode Meloidogyne incognita eggs. Biocontrol Sci. Technol. 17:1047-1058.

Nitao, J. K., Meyer, S. L. F., and Chitwood, D. J. 1999. In-vitro assays of Meloidogyne incognita and Heterodera glycines for detection of nematodeantagonistic fungal compounds. J. Nematol. 31:172-183.

Quesenberry, K. H., Baltensperger, D. D., Dunn, R. A., Wilcox, C. J., and Hardy, S. R. 1989. Selection for tolerance to root-knot nematodes in red clover. Crop Sci. 29:62-65.

Shinya, R., Aiuchi, D., Kushida, A., Tani, M., Kuramochi, K., and Koike, M. 2008. Effects of fungal culture filtrates of Verticillium lecanii (Lecanicillium spp.) hybrid strains on Heterodera glycine eggs and juveniles. J. Invertebr. Pathol 97:291-297.

Singh, S., and Mathur, N. 2010. In-vitro studies of antagonistic fungi against the root knot nematode, Meloidogyne incognita. Biocontrol Sci. Technol. 20: 275-282.

Tikhonov, V. E., Lopez-Llorca, L. V., Salinas, J., and Jansson, H. B. 2002. Purification and characterization of chitinases from the nematophagous fungi Verticillium chlamydosporium and $V$. suchlasporium. Fungal Genet. Biol. 35:67-78.

Topp, E., Miller, S., Bork, H., and Welsh, M. 1998. Effects of marigold (Tagetes sp.) roots on soil microorganisms. Biol. Fertil. Soils 27:149-154.

Wekesa, V. W., Maniania, N. K., Knapp, M., and Boga, H. I. 2005. Pathogenicity of Beauveria bassiana and Metarhizium anisopliae to the tobacco spider mite Tetranychus evansi. Exp. Appl. Acarol. 36:41-50.

Whitehead, A. G. 1998. Sedentary endoparasites of roots and tubers (Meloidogyne and Nacobus). Pages 209-260 in: Plant Nematode Control. CAB International, Wallingford, U.K. 
Whitehead, A. G., and Hemming, J. R. 1965. A comparison of some quantitative methods of extracting small vermiform nematodes from soil. Ann. Appl. Biol. 55:25-38.

Williamson, V. M., and Hussey, R. S. 1996. Nematode pathogenesis and resistance in plants. Plant Cell 8:1735-1745.

Wyss, U., Grundler, F. M. W., and Munch, A. 1992. The parasitic behaviour of second stage juveniles of Meloidogyne incognita in root of Arabidopsis thaliana. Nematologica 38:98-111.

Yang, J. K., Huang, X. W., Tian, B. Y., Sun, H., Duan, J. X., Wu, W. P., and Zhang, K. Q. 2005. Characterization of an extracellular serine protease gene from the nematophagous fungus Lecanicillium psalliotae. Biotechnol. Lett. 27:1329-1334.
Yang, J. K., Tian, B. Y., Liang, L. M., and Zhang, K. Q. 2007. Extracellular enzymes and the pathogenesis of nematophagous fungi. Appl. Microbiol. Biotechnol. 75:21-31.

Zare, R., and Gams, W. 2001. A revision of Verticillium section Prostrata. IV. The genera Lecanicillium and Simplicillium. Nova Hedwigia 73:1-50.

Zare, R., and Gams, W. 2008. A revision of the Verticillium fungicola species complex and its affinity with the genus Lecanicillium. Mycol. Res. 112:811-824.

Zare, R., Gams, W., and Culham, A. 2000. A revision of Verticillium sect. Prostrata. I. Phylogenetic studies using ITS sequences. Nova Hedwigia 71: 465-480. 